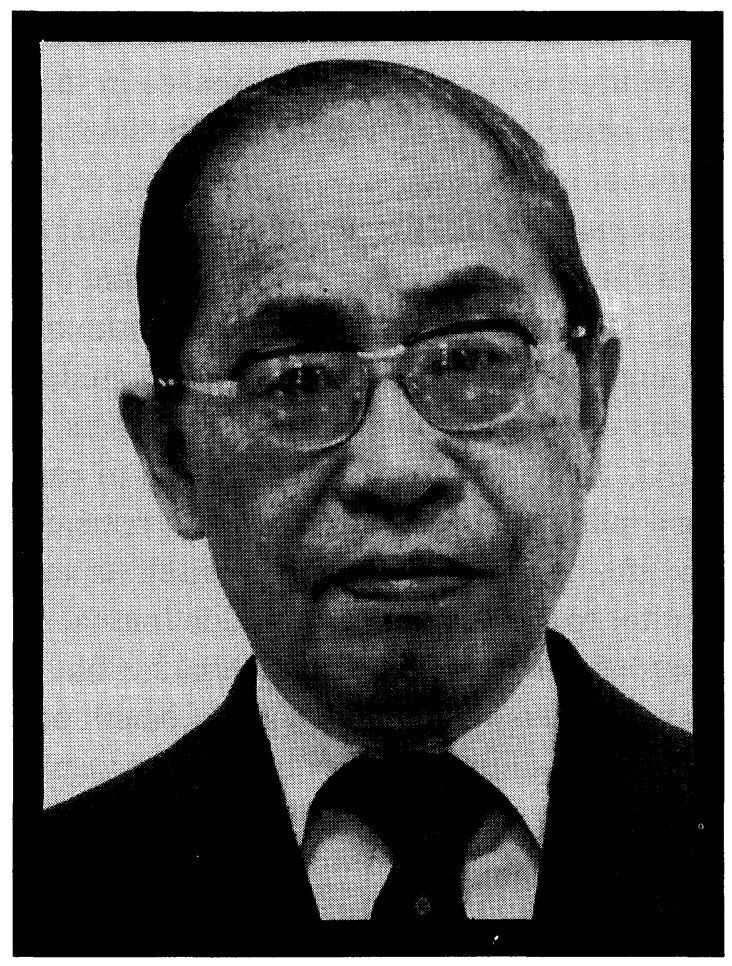

Hiroyuki Sakabe, MD (1915-1997)

\title{
IN MEMORIAM: Hiroyuki SAKABE, MD
}

On March 16, 1997, Hiroyuki Sakabe, MD, passed away, and we lost a leading scientist and occupational health physician, judicious editor, and ex-editor-in-chief and founder of INDUSTRIAL HEALTH. On behalf of the Editorial Board of INDUSTRIAL HEALTH and the National Institute of Industrial Health, I express my deepest condolences to his wife and family and share a profound sadness in the loss of our beloved leader with all who have been concerned with the prevention of occupational diseases and the promotion of workers' health.

Dr. Sakabe was born on August 9, 1915, and graduated from Okayama Medical College in 1939. He started his research career at the Institute of Public Health with directorship of Dr. Tomoyoshi Ishikawa who later became Professor of Tokyo University Medical School. At first, Dr. Sakabe investigated acute $\mathrm{CO}$ poisoning in the engineer of steam locomotive passing through the long tunnel and recognized the importance of both exposure assessment and technological countermeasures in work environment. Unhappily, World War II interrupted his research career and he was drafted as a medical officer. Moreover, it was with his single-minded conscience as a physician that he stayed in a Siberian camp to treat many Japanese prisoners of war for three years after the end of World War II. After returning to Japan, he enthusiastically carried out research on occupational and environmental health for nine years at the Institute of Public Health. 
In 1957, the National Institute of Industrial Health was established in the Ministry of Labor for the prevention of occupational diseases in the wake of industrial reconstruction and development in post-war Japan. Dr. Sakabe's vast and profound knowledge of occupational health, industrial hygiene, and occupational physiology enabled him to serve successfully as Director of Occupational Diseases Department and then as Director of Environmental Hygiene Department and finally as Director of Industrial Physiology Department, all at the National Institute of Industrial Health. His great intellectual, creative and communicative skills guided young scientists in original work and encouraged them to write scientific papers. In 1963, Dr. Sakabe founded INDUSTRIAL HEALTH for the publication of research pertaining to occupational health and industrial hygiene. It should be remembered that from 1963 to the very end of his life, he fervently devoted himself as an editor, ex editor-inchief, and advisory editor to the development of this Journal as one of the leading occupational health journals in the world. Throughout his life, he continued to look carefully and intellectually into a broad spectrum of health problems of work and workers with wide vision and deep insight with which he inspired young scientists. In 1976, the National Institute of Industrial Health was expanded from three to six research departments. The reorganization would not have been realized without the strenuous, meticulous efforts of Dr. Sakabe. From 1977 to 1985, he undertook the demanding position of Director General of the newly reorganized National Institute of Industrial Health. Throughout the many years he served as Director and then as Director General of the National Institute of Industrial Health, his unparalleled achievements were not limited to his zeal to encourage and inspire many young researchers to pursue original research, but also made great contributions to the official recognition of occupational diseases and the setting up of occupational health-related laws, guidelines and standards as a chairperson of various governmental committees. Amidst busy administrative work, he also pursued his own research with vision and insight. One of his many papers, entitled "Lung cancer due to exposure to bis(chloromethyl)ether", was published in this Journal, Vol. 11 (1973), 145-148, and ultimately contributed to the official issue of Personal Health Record for the prevention of occupational cancer among workers who deal with this compound. This epidemiological article has been widely recognized as one of the most influential studies in occupational cancer (see Cancer Research Vol.50 (1990), No.1, 1354 and Dr. Sakabe's portrait on the cover page).

In 1988, Dr. Sakabe was awarded the Order of Sacred Treasure, Gold and Silver Star for his great contributions to occupational health and industrial hygiene. In celebrating the memory of Dr. Hiroyuki Sakabe, the legacy which he left to us will inspire us to strive for what is the best in research on occupational health, the prevention of occupational diseases, and the promotion of workers' health.

Haruhiko Sakurai, MD, DMSc, MPH

Editor-in-chief, INDUSTRIAL HEALTH,

Director General, National Institute of Industrial Health 